\title{
Types of Slang Words in the Movie Script of Sausage Party
}

\author{
I Made Yoga Darma Putra \\ English Department, Faculty of Arts, Udayana University \\ [madeyoga91@gmail.com],
}

\begin{abstract}
This paper entitled "Types of Slang Words in Sausage Party Movie Script"is aimed to analyze the types of slang words and their types of meaning found in the Sausage Party movie script. The data were taken from internet on Tuesday September 5, 2017. In analyzing the types of slang words and the types of meaning used, descriptive qualitative method and theory proposed by Allan and Burridge (2006) that consists of five types and supporting theory proposed by Geoffrey Leech (1974) that consists of seven types were used. The result shows that there are fifty slang expressions analyzed in this study. The major slang used in this movie script is formed by two or more words and achieve it own meaning that are different from the source word. The slang meaning found in this study mostly express the implicit meaning of the expression. It can be concluded that Sausage Party movie script has a relatively exclusive language.
\end{abstract}

Keywords: Movie script, Slang language, sausage, party.

\begin{abstract}
Abstrak
Makalah ini berjudul "Jenis Kata-kata Slang di Naskah Film "Sausage Party" yang bertujuan untuk menganalisis jenis kata-kata slang dan jenis maknanya yang ditemukan pada naskah film "Sausage Party". Data diambil dari internet pada hari selasa tanggal 5 september 2017. Dalam menganalisis jenis kata slang dan jenis makna yang digunakan, dipakai metode kualitatif deskriptif dan teori yang diajukan oleh Allan dan Buridge (2006) yang terdiri dari lima tipe dan teori pendukung yang diajukan oleh Geoffrey Leech (1974) yang terdiri dari tujuh tipe. Hasilnya menunjukan bahwa ada lima puluh kata-kata slang yang dianalisa dalam penelitian ini. Mayoritas bahasa slang yang digunakan dalam naskah film ini dibentuk dari dua kata atau lebih dan mendapatkan makna tersendiri yang berbeda dengan kata aslinya. Makna kata-kata slang yang ditemukan dalam penelitian ini kebanyakan mengungkapkan makna implicit dari ekspresi. Dapat disimpulkan bahwa naskah film "Sausage Party" memiliki bahasa yang relatif eksklusif.
\end{abstract}

Kata kunci: Naskah film, Bahasa slang, sosis, pesta.

\section{Background of the Study}

Slang is one of the language choices used in informal context and normally used by people in a certain group or community. The use of slang is unsuitable for formal situation, but perfect for informal situation. According to Chapman (2007), slang is the nonlinguistic sort of language and that it mostly ignores the main aim of a language. The slang language itself is designed to be more casual and informal to make the conversation gobetter. Teenagers or people in a certain group or 
community are the ones who are mostly responsible for the occurrence of slang words. Slang words spread into worldwide due to many factors. Usually, people learn slang words from entertainment mediasuch as song, novel and movie.

Movie is one of the media besides song or novel that gives a lot of impact on spreading slang words worldwide. In a movie, movie script is produced to lead the character's performance in their play. One of the movie scripts produced slang words is entitled Sausage Party. Sometimes the slang words are difficult to understand and it would be hard for the audience to follow the story of the movie. This movie script is analyzed in order to understand the type of slang words and type of meaning used in this movie script.

\section{Problems of the Study}

a. What types of slang words used in Sausage Party movie script?

b. What types of meanings of slang words used in Sausage Party movie script?

\section{Aims of the Study}

a. To identify the types of slang words found in the Sausage Party movie script.

b. To find out the type of meaning of slang words occurring in the Sausage Party movie script.

\section{Research Method}

There are four points of discussion covered in this section; they are data source, method and technique of collecting data, method and technique of analyzing data, method and technique of presenting analysis.

\section{a. Data source}

The data in this study were taken from a movie script entitled Sausage
Party, downloaded from http://archive.is/0eWWi on Tuesday September 5, 2017 used as the primary data. The movie script was chosen as the data source in this study. The movie script entitled Sausage Party has the slang word varieties in the dialogue and almost all off the dialogues in this movie consist of one or more slang words.

\section{b. Method and technique of collecting data}

The data of the study were collected by means of documentation. Documentation is the method for gathering information by giving a record report of certainties of something, particularly by utilizing pictures, note taking and recording. The first step needed was to read the Sausage Partymovie script. The second step was identifying and taking note of slang words from the movie script.

\section{c. Method and technique of analyzing data}

Qualitative methodwas applied in analyzingthe collected data in this study. The descriptive technique was applied by describing the content of the writing to the readers clearly. The process of analyzing data wasdong through two steps; the first step was identifying and classifying the data according to the types of slang words found in the Sausage Party movie script using the theory proposed by Allan and Burridge (2006). The second step was analyzing the meaning of slang expressions found in the Sausage Party movie script using the theory proposed by Geoffrey Leech (1974).

\section{d. Method and technique of presentingthe result of data analysis}

Informal method wasapplied in this study in order to present the first and 
second problem analysis. Informal method refers to method that describes the data using words. In regard to explain the categorization from slang words and phrases, the forms of paragraph were used in the data presentation in order to give more elaboration about the data. The paragraph explained some of the slang expressions and a small portion of explanation about the situation of dialogue where the slang expressions were found. For example:

Clipping is a type of slang word that occurred when a word is delted in one or some parts but still have the same meaning as the uncut one. In this case, the word bro is a cut word or part of the word brother, which has the same meaning from the original word. The slang word bro occurred in the dialogue when Douche talking with Cocktail Mixer in the shopping cart. Douche used the slang word bro to refer to Cocktail Mixer in the dialogue.

\section{Analysis of Types of Slang Words and Types of Meaning of Slang Words}

This chapter begins from the analysis of slang words used in conversations by the characters in certain scenes. The use of movie script entitled Sausage Party is to discuss several research questions are concerned with slang words. The data in this study were analyzed in three steps. The first step was classifying the data into five types based on slang word theory. The second step is how the data analyzed using the types of meaning theory. The last part was analyzing the data to provide further elaboration on the data.

\subsection{The Analysis of Types of Slang Words in Sausage Party}

This part focuses on describing the findings and analysis of types of slang expressions found in the movie script entitled Sausage Party. The data were classified based on their slang types using the theory proposed by Allan and Burridge (2006) which divided the data into 5 types, such as fresh and creative, flippant, imitative, acronym, and clipping. The analysis is as follows.

\section{Fresh and Creative}

The type fresh and creative is a type where the slang word has a brand new vocabulary, cleverness imagination, informal variety and can be an up to date words or even old words that people do not know. Several slang expressions found in this study were categorized into fresh and creative wordsnerd from deformed nerd, nah, dudes,cray-cray, biggie, yoand babe. One of the examples is the word cray-cray mentioned in the dialogue. The word cray-cray shows that the slang word keeps improving by using new wordcreatedthrough imagination. The other slang word example is biggie. This slang word comes as a new vocabulary and cleverness imagination from the speaker. There are also slang words of yoand babe used in the dialogue to call or refer to someone and creates an informal situation with their informal variety.

\section{Flippant}

The key to grouping slang word into flippant is when slang form consists of more than two words and does not have any relationship to the denotative meaning. Several slang expressions found in this study categorized into flippant type are kick your ass, full of shit, fucking nuts, flying fuck, super baked, deformed nerd, fucking much, fucking 10, dark lord, dumb-ass, fucking cunt, fucked out, fucked up, clean high, calm down a notch, where the fuck and kiss my brownish-yellow ass. One of the examples is the phrase fucked out, which are categorized into flippant. The phrase 
fucked out consists of two words that are fucked and out. Each of the two words has different meaning or their own but when the two words are put together into one phrase or more the meaning is different from the original words. The other example is fucking cunt which is the same as the phrase fucked out, the phrase fucking cunt consists of two words, which are fucking and cunt. However, when combined they achieved their own meaning and are clearly different from the meaning of the original word meaning.

\section{Imitative}

Imitative is a form of slang word type, which imitates the other words or combination of two words that result in different meaning. Several slang expressions found in this study are categorized into imitative type; they are wanna, ain't, gotta, gonna, shit, motherfuckers, prick, bullshit, shitty, jackrabbit, damn, asses, asshole, flappyfuck, cocksucking, fuckface, sucks, fucky, fucked, pussy, bitches, dicks, and cool. One of the examples isbitches, the word sucks is a kind of slang word that fully imitates the original word but has different meaning than the original word. The original word bitches has a meaning of female dogs but change into a word that refer to people in the dialogue. The other example is wanna. The words wanna is the slang words which originate from two words combined into one and achieve its own meaning. The word wanna is originated from the word want and tocombined into one word.

\section{Acronym}

Acronym type is the type of slang word that uses the first letter of each word to make an acronym. What makes it different from standard acronym is that the acronym is read as a word. There is a slang expression of MILFcategorized into acronym typefound in this study. In the script uttered by Darren contains the slang word MILF. The slang wordMILF is an example where this type is used and the word itself still has its original meaning. The word MILF itself is acronym from Mother I'd Like to Fuck according to the urban dictionary.

\section{Clipping}

Clipping type is a type of slang word when a word is deleted in one or some parts but still has the same meaning as the uncut one. The deletion of some parts of the word in slang expression is one of the forms of the usage of imagination and effort to reach certain point in communication.This imagination and effort only apply in certain group or place. The slang wordbro found in this study is categorized into clipping type. In the script uttered by Douche contained the slang word bro. The word bro is a slang word where the original word is brotherand the ther partis deleted and still has the word meaning referred by Douche.

\subsection{The Analysis of Types of Meaning of Slang Words in Sausage Party}

This part only focuses on the analysis of types of meaning found in the movie script entitled Sausage Party. For the type of meaning, the slang wordmeaning is analyzed by using the theory proposed by Leech (1974) which distinguishes the slang words into seven types, such as conceptual or denotative meaning, connotative meaning, social meaning, affective or emotive meaning, reflected meaning, collocative meaning, and thematic meaning. The analysis is as follows:

\section{Conceptual}

Conceptual meaningis a core meaning; unlike the other meaning, which consists of peripheral meaning. 
Several slang expressions found in this study are categorized into conceptual type of meaning such ascray-cray, deformed nerd, MILF, nah,wanna, ain't, gotta, gonna, calm down a notch, where the fuck, and biggie. Those slang expressions can differ according to what they represent, such as attitude, person, thing, and situation. There is also a conceptual type of meaning that explicitly uses affective type of meaning that expresses anger. For example;

\section{a. Cray-cray}

The slang expression cray-cray is the first example of slang expression that represents attitude as its meaningin this study. This expression appears in the dialogue, this part starts when Honey Mustard is in a cart and panicked. The Honey Mustard is panicked and scared when he is put in the cart. Then, Carl complains to him for making ruckus in the cart. The dialogue happened between Honey Mustard, Carl and Brenda, when complaining; Carl said, "Honey Mustard, you acting cray-cray!" The slang word cray-crayis categorized into conceptual or denotative meaning because the word cray-cray has neutral meaning,that is, the same as in the dictionary, a word without any associative meaning. Conceptual meaning is the only in its kind which has core meaning. The word cray-cray has literal meaning whiny.

\section{Connotative}

The connocative meaning is the meaning that slang expression has which is used to express the communicative value above the core meaning of the word.Connotative meaning mostly occurs in conversation. Each of the slang expression has meaning that hold the properties of a word from point of view, which is already cling to each individual, group, and even the society. Several slang expressions found in this study are categorized into conceptual type of meaning.They are motherfuckers, prick, bullshit, shitty, jackrabbit, kick your ass, full of shit, fucking nuts, flying fuck, super baked, fucking much, damn, fucking 10, asses,dark lord, asshole, flappyfuck, dumb-ass, cocksucking, fuckface, fucking cunt, sucks, fucky, fucked out, fucked up, fucked, clean high,shit and kiss my brownish-yellow ass. The connotative type of meaning can differentiate according to what it representd, such as attitude, condition, emphasis, person, rule, and situation. Other than connotative meaning, there also exists affective meaning in some of the slang words that represent anger, hate passionate, scared and awe. For example:

\section{a. Full of shit}

Full of shit is the slang phrase that represents attitude from someone and this slang phrase also explicitly expresses anger from the speaker, the dialogue in this part starts when Troy continued mocking Barry. The dialogue happened between sausages, where troy mocked Barry and Frank encouraged him. When Frank uttered, "Ignore that prick, Barry. He's full of shit. and don't forget, you've got girth." It contains the slang word full of shit. The word full of shit found in this dialogue is categorized into connotative meaning because it has meaning that is different from its conceptual meaning. In literal meaning the slang expression full of shit has the meaning of fully filledwith feces. According to the urban dictionary, full of shit refers to someone who is not credible. In order to mock Troy the phrase full of shit is uttered in this scene.

\section{Social Meaning}

The social meaning using the social context from the slang word itself is used to deliver the meaning of the slang words. The point of view in 
understanding social meaning will vary. It means each person has different level and variation in social knowledge that makes it vary. On the other hand, dialect is also the factor of recognizing some words. In the end, the defining factor is the relation between the social meaning and the usage of situation in the utterance. Several slang expressions found in this study categorized into conceptual type of meaning aredudes, bro, yoand babe. Both slang expressionsare intended to show friendliness and intimate relation. Therefore, it shows the speaker. For example:

\section{a. $Y o$}

The slang word yois one of the slang words where the word is used to make the situation less formal. The slang word yois a way to express greeting or say hello to friends. The slang occurs in this part of dialogue, when Douche gives greeting after talking with Chips. The dialogue happened between Douche and Cocktail mixer, where Douche greeted the Cocktail Mixer and started to quip him. When Douche was uttering, "Yo, are you pink all the way through?" There contains the slang word yo. The use of the slang word yois intended to show friendliness to the target speaker, in this case, Cocktail Mixer.

\section{Affective Meaning}

The usage of slang expression based itself on the expression of emotion expressed by the speaker or the writer about something that usually happens in daily conversation. The expression happened in order to deliver the speaker's personal feeling to the listener or reader. Several slang expressions found in this study are categorized into affective type of meaning. They are fuck off, fuck you, where the fuck, motherfucker, prick, bullshit, shitty, kick your ass, full of shit, fucking nuts, flying fuck, super baked, fucking much, damn, fucking 10, asshole, flappyfuck, dumbass, cocksucking, fuckface, fucking cunt, sucks, fucked out, fucked up, fucked, kiss my brownish-yellow ass, bitches and dicks. All of these slang expressions are slang words that have the affective meaning type occurring explicitly together with another type in one slang expression. In this study emotion from the use of affective meaning in the slang expressions, such as happy, surprised, anger, awe, passionate, scared and hate can be observed. For example;

\section{a. Kiss my brownish-yellow ass}

The first example is the slang phrase Kiss my brownish-yellow ass! That is intended to express hate from the speaker. The part in this dialogue starts when the Honey Mustard being picked by the god when the other food in the aisle singing. The Honey Mustard feels happy for being chosen by the god. Honey Mustard uttered his expression to the other food in the aisle. The dialogue happened one way, from the mustard to the foods in the aisle. When expressing his feeling Honey Mustard uttered, "Kiss my brownishyellow ass! I'm going to the Great Beyond, motherfuckers!" In the dialogue, the slang phraseKiss my brownish-yellow assis contained. The phrase Kiss my brownish-yellow assis categorized ashaving affective or emotive meaning for straightly expressing the speaker's feeling. The phrase Kiss my brownishyellow ass is intended to express that the Honey Mustard hates the other food in the aisle.

\section{Reflected Meaning}

Reflected meaning is the type of meaning that occurred from a word that consists of two or more conceptual meanings or called multiple conceptual meaning. We could say that when one word is 
conveyed we got the word sense and catch a glimpse of another sense. Several slang expressions found in this study that are categorized into conceptual type of meaning are pussy, bitches, dicks, and cool. Slang words categorized as having reflective meaning found in this study also expressed affective meaning explicitly. The affective meaning found was used to convey the feeling of hating someone from the speaker. For example;

\section{a. Pussy}

The first example of reflective slang word is pussy. This slang word pussy represents a person in this part of dialogue. The part of the dialogue happened when a sausage named Troy was mocking Barry. The dialogue happened between sausages, When Troy was uttering, "Well, Barry, I guess now you're weird and a pussy. Add that to your list of accomplishments" The slang word pussy is contained. The word pussyis categorized as having reflective meaning. In this case, the meaning of the word pussy is used in this dialogue cowardly. Troy uttered the word pussy in this scene for mocking Barry's attitude that is too coward.

\section{Collocative}

When a slang expression acquires its own meaning thatoccurrs because of acquiring company meaning from a certain word, it will lose the original meaning and changes into new one. Two slang expressions found in this study are categorized into conceptual types of meaning; they arefuck off and fuck you. The slang expression categorized as having reflective meaning can differ based on what slang expression represents action and situation. There also exist slang expressions that explicitly express emotion from the speaker such as hate and anger. For example;

\section{a. Fuck off}

Fuck off is one of the collotative slang expressions found in this study. The slang expression fuck off representsan action and explicitly conveys emotive meaning from the speaker. The slang word occurs in the dialogue when Honey Mustard is questioned by ketchup and it starts the part in this dialogue. In the distance Firewater appeared and threatened Honey mustard if Honey Mustard was trying to say everything he saw in The Great Beyond. When Firewater disappears, Honey Mustard want ketchup to get away from him and utters "Ketchup, fuck off. Nobody touch me!" The phrasefuck offis categorized into havingcollotative meaning. The phrase fuck off has its meaning from the word fuckwhich collocates with the word off. The word fuck that means sexual action and off that represents away from the place collocate into one which acquires its own meaning. According to the dialogue, the slang phrase fuck offis uttered by Honey Mustard when he is in trouble being threatened by Firewater. The slang phrase fuckoffis conveyed to make other get off from honey mustard. In addition, the word fuck off also explicitly expresses hating from Honey mustard to the other food who wants to help him.

\section{Conclusions}

Based on the previous discussion of analyzing slang words of Sausage party movie script, it can be concluded that the types of slang words which are based on the theory proposed by Allan and Burridge (2006), there are five types of slang words found in this study. They are; flippant, imitative, fresh and creative, clipping andacronym. Generally, the types of slang wordsused in this movie script is 
flippant.The major usage of flippant type because of the fact that almost all of the slangs used in this movie script are formed from two or more words and achieves their own meanings, which are different from the source words.

Other than the type of slang words, the study also discusses the types of meaning proposed by Leech (1974). There are six types found in this study. They are connotative, conceptual, affective, reflected, social and collocative meanings. The majority usage of this types in this movie script is the connotative meaning where the word meaning expresses the communicative value above the core meaning of the word itself. There is a type of meaning which does not occurr in this movie script, namely thematic meaning. The absence of thematic type of meaning in movie script entitled Sausage Party showsthat the form in which the message is organized in terms of order affects none of the slang words or phrases found in this movie script. In other words, the usage of passive or active sentence in this study is not concerned with the occurrence of slang expressions.

\section{References}

Allan, K., Burridge, K. (2006). Forbidden Words: Taboo and The Censoring of Language. Cambridge: CUP.

Chapman, Robert L. 1998. A New Dictionary of American Slang. London: Harper \& Row Publishers Inc.

Leech, Geoffrey. 1974. Semantics: The Study of Meaning. Harmondsworth: Penguin.

Sausage Party (2016) Movie Script[internet]. Available from: http://archive.is/0eWWi [Accessed on Tuesday September 5, 2017] 